\title{
The c-myc and PyMT oncogenes induce different tumor types in a somatic mouse model for pancreatic cancer
}

\author{
Brian C. Lewis, ${ }^{1,3,4}$ David S. Klimstra, ${ }^{2}$ and Harold E. Varmus ${ }^{1}$ \\ ${ }^{1}$ Cancer Biology and Genetics Program and ${ }^{2}$ Department of Pathology, Memorial Sloan-Kettering Cancer Center, \\ New York, New York 10021, USA
}

\begin{abstract}
We have generated a mouse model for pancreatic cancer through the somatic delivery of oncogene-bearing avian retroviruses to mice that express TVA, the receptor for avian leukosis sarcoma virus subgroup $A$ (ALSV-A), under the control of the elastase promoter. Delivery of ALSV-A-based RCAS vectors encoding either mouse polyoma virus middle $\mathrm{T}$ antigen (PyMT) or c-Myc to elastase-tv-a transgenic, Ink4a/Arf null mice induced the formation of pancreatic tumors. RCAS-PyMT induced pancreatic tumors with the histologic features of acinar or ductal carcinomas. The induced pancreatic lesions express Pdx1, a marker for pancreas progenitor cells, and many tumors express markers for both exocrine and endocrine cell lineages, suggesting that the tumors may be derived from progenitor cells. In contrast, RCAS-c-myc induced endocrine tumors exclusively, as determined by histology and detection of differentiation markers. Thus, specific oncogenes can induce the formation of different pancreatic tumor types in a single transgenic line, most likely from one or more types of multipotential progenitor cells. Our model appears to be useful for elucidating the genetic alterations, target cells, and signaling pathways that are important in the genesis of different types of pancreatic cancer.
\end{abstract}

[Keywords: RCAS; PyMT; c-Myc; pancreatic cancer; progenitor cell; transdifferentiation]

Received August 4, 2003; revised version accepted November 11, 2003.

The pancreas is composed of two major compartments, the exocrine pancreas, which consists of the digestive enzyme-producing acinar cells and the ducts that conduct these enzymes to the intestines, and the endocrine pancreas, composed of the hormone-producing cells in the islets of Langerhans. All of these cells arise developmentally from a common endodermally derived pancreas progenitor cell marked by the expression of the transcription factor Pdx1 at embryonic day 9.5 (Jonsson et al. 1994; Offield et al. 1996; Edlund 2001, 2002). Pdx1positive cells give rise to neurogenin (Ngn) 3-positive cells, the precursors of islet cells, and PTF1-p48 positive cells, from which acinar cells, ductal cells, and some islet $\alpha$ - and $\beta$-cells are derived (Fig. 1; Schwitzgebel et al. 2000; Gu et al. 2002; Kawaguchi et al. 2002).

Pancreatic carcinoma is the fifth leading cause of cancer-related deaths in the United States, with an estimated 30,000 deaths each year (Jemal et al. 2002). Tumors arise in the pancreas with the features of the three major cell types of the pancreas - the acinar cells, endo-

\footnotetext{
${ }^{3}$ Present address: University of Massachusetts Medical School, 364 Plantation Street, LRB 521, Worcester, MA 01605, USA.

${ }^{4}$ Corresponding author.

E-MAIL brian.lewis@umassmed.edu; FAX (508) 856-4650.

Article published online ahead of print. Article and publication date are at http://www.genesdev.org/cgi/doi/10.1101/gad.1140403.
}

crine cells, and the pancreatic duct cells. Speculation about the cellular origins of pancreatic tumors is based largely on the histological appearance of the tumors, the existence of putative precursor lesions in a specific cellular compartment, and the presence of proteins that identify the corresponding normal cellular counterpart.

Molecular genetic analysis of human pancreatic cancers has revealed that the different histologic types harbor different genetic alterations. Ductal adenocarcinoma, which accounts for $80 \%-85 \%$ of cases, has activating mutations in the $K-R A S 2$ oncogene in $>90 \%$ of cases, as well as loss of the INK4A locus encoding the p16 tumor suppressor protein (Bardeesy and DePinho 2002; Jaffee et al. 2002). In addition, the TP53 and $\mathrm{MADH} 4$ tumor-suppressor genes are functionally inactivated in over half of the cases (Bardeesy and DePinho 2002; Jaffee et al. 2002). In contrast, acinar carcinomas frequently contain alterations in the APC or CTNNB1 genes, which lead to deregulated Wnt signaling, but do not harbor mutations in the genes encoding K-Ras, p16, Smad4, or p53 (Abraham et al. 2002; Bardeesy and DePinho 2002).

Several tumors composed of mixed acinar and endocrine cell populations have been described (Klimstra et al. 1994). Whereas the tumors appear homogenous histologically, the individual cell types are readily identi- 


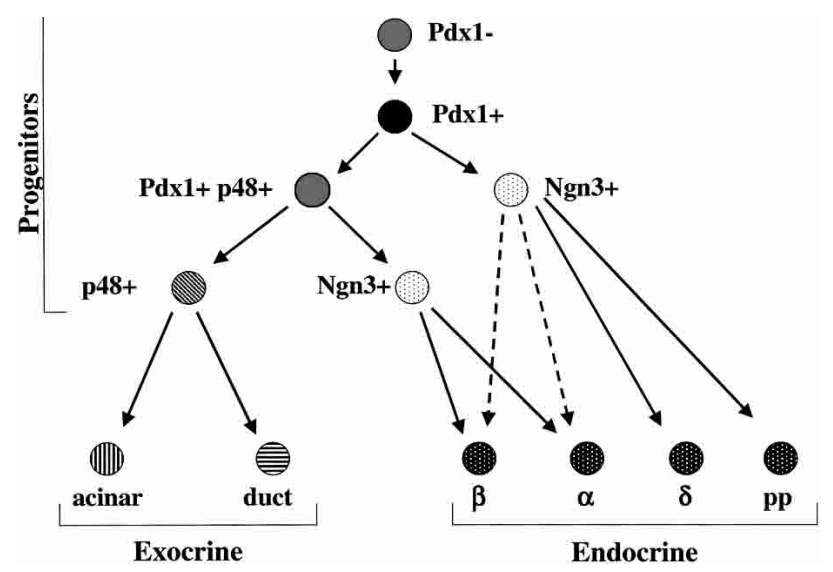

Figure 1. Model for the development of the cell lineages of the pancreas. The pancreatic bud forms concomitant with the induction of Pdx1 expression. All pancreatic cell lineages are derived from a Pdxl-positive progenitor. The acinar, islet, and ductal lineages diverge between E9.5 and E12.5 with the onset of PTF1-p48 expression. The majority of $\alpha$ - and $\beta$-cells are derived from a PTF1-p48-positive precursor (solid lines), whereas a smaller percentage are generated from another precursor that does not express PTF1-p48 (Kawaguchi et al. 2002).

fied by staining for lineage-specific markers, supporting the idea that these tumors could be derived from a progenitor-like cell able to give rise to multiple cell types (Klimstra et al. 1994). These findings have contributed to an ongoing debate over whether different pancreatic tumor types arise from the transformation of distinct target cells or whether they arise from a common precursor(s) with the tumor type determined by the genetic alterations present within the tumor. Therefore, a model system that can be used to address these issues would be a very valuable tool in the study of pancreatic cancer.

Mouse tumor models offer genetically tractable systems in which to analyze the effects of specific genetic alterations on the tumor type. Over a decade ago, Brinster, Palmiter, and colleagues generated a series of transgenic lines that expressed various oncogenes under the control of the pancreas-specific elastase promoter (Ornitz et al. 1987; Quaife et al. 1987; Sandgren et al. 1990, 1991). These transgenic mice developed primarily acinar cell carcinomas or mixed acinar and ductal carcinomas. More recently, Schmid and colleagues characterized elastase-TGF- $\alpha$ transgenic mice in greater detail. They demonstrated that these mice developed pancreatic ductal lesions that progressed to carcinoma with a long latency (Wagner et al. 1998). The absence of p53 led to dramatic acceleration of tumorigenesis, and some tumors displayed loss of the Ink $4 a$ and Madh4 loci, confirming the importance of these loci in pancreatic adenocarcinoma development (Wagner et al. 2001).

We have now developed a novel mouse model for pancreatic cancer using the RCAS-TVA gene delivery system, which permits the introduction of genes into somatic cells in a tissue-specific manner, and the evaluation of the effects of different genes in a single transgenic mouse line (Fisher et al. 1999; Orsulic 2002). We gener- ated a transgenic line in which TVA expression is targeted to the pancreas by the elastase promoter (Ornitz et al. 1985; Kruse et al. 1993). Infection of elastase- $t v-a$ transgenic mice, either wild type or null for the Ink4a/ Arf locus, with viruses encoding mouse polyoma virus middle $\mathrm{T}$ antigen, induced highly penetrant acinar and ductal tumors. The tumors expressed markers for both exocrine and endocrine lineages, as well as the progenitor cell marker Pdx1. In contrast, infection of elastase$t v-a$, Ink $4 a / A r f$ null mice with viruses encoding the cMyc oncoprotein led to the formation of pancreatic endocrine tumors exclusively. These data demonstrate that specific oncogenes introduced somatically into the same set of infectable cells can induce very different tumors.

\section{Results}

\section{Generation of elastase-tv-a mice}

We sought to produce a new somatic mouse model for tumors of the exocrine pancreas utilizing the RCASTVA system. To generate mice that are susceptible to infection by ALSV-A-based RCAS vectors specifically within the pancreas, we generated transgenic mice expressing $t v$ - $a$ under the control of the elastase promoter (Fig, 2A). This promoter has been used previously in transgenic mice with the intent of expressing genes specifically in the acinar cells of the pancreas (Ornitz et al. 1985, 1987; Kruse et al. 1993).

To detect TVA on the surface of pancreatic cells in elastase- $t V-a$ transgenic mice, we performed immunofluorescent staining with affinity-purified anti-TVA rabbit serum on pancreas sections from transgenic mice. In samples from adult animals, TVA was observed, as expected, only on cells within acini, and was absent from the ducts $\left(^{\star}\right)$ and islets (I) (Fig. 2B). No TVA staining was seen in pancreases from nontransgenic littermates (Fig. 2B). TVA was not detected in the liver, lung, spleen, or kidney of elastase- $t v-a$ transgenic mice by RT-PCR (data not shown).

Because RCAS viruses, like other oncoretroviruses, require cell division for the integration of the newly synthesized viral DNA into the host genome (Miller et al. 1990; Roe et al. 1993; Lewis and Emerman 1994), we assessed the number of replicating cells in the adult pancreas with antibodies against the S-phase marker Ki67. Ki67 staining of pancreases from adult animals demonstrated low levels of proliferation within the pancreas (Fig. 2C, left). In contrast, abundant proliferating cells were present within the pancreas of animals at postnatal day 2 (Fig. 2C, right).

We therefore tested pancreases from newborn mice for the expression of TVA. Immunofluorescent staining with TVA antiserum readily detected the viral receptor in a large proportion of pancreatic cells (Fig. 2D). Again, no staining was seen in pancreases from nontransgenic littermates. In contrast to the acinar-specific staining seen in the adult pancreas, TVA appeared to be more widely distributed throughout the pancreas. To confirm the presence of TVA outside the acinar compartment, we performed double immunofluorescence experiments 
B

Adult Transgenic

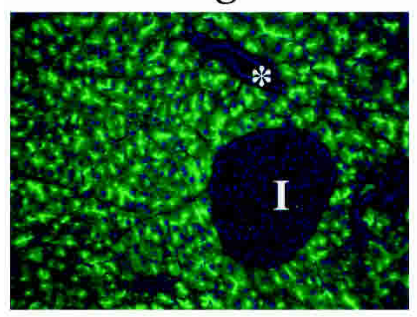

D

P2 Transgenic

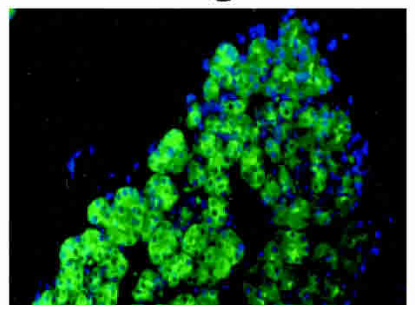

Adult Non-transgenic

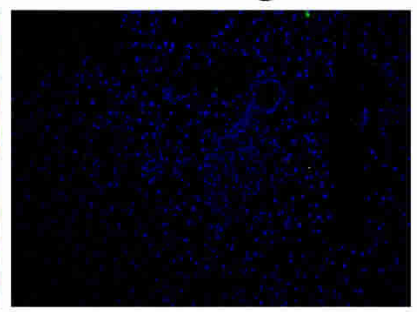

P2 Non-transgenic

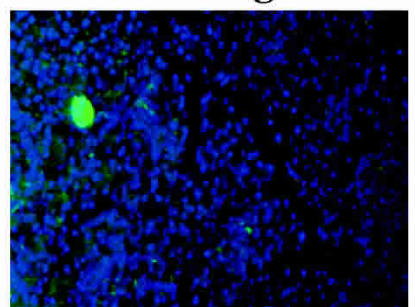

C

Adult

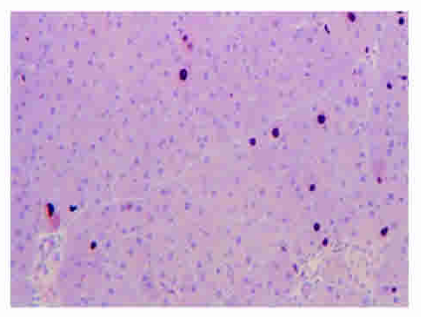

P2

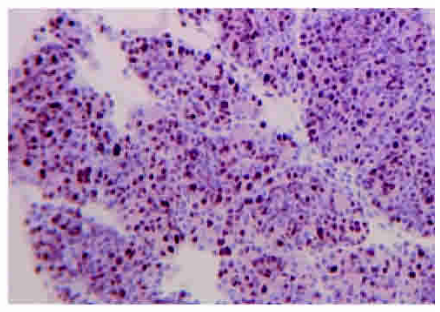

$\mathbf{E}$

Figure 2. Characterization of elastase- $t v-a$ transgenic mice. $(A)$ Schematic of the elastase- $t v-a$ transgene. The $800-b p t v-a$ cDNA fused to SV40 intron and poly(A) sequences (gift of G. Fisher) was placed downstream of the 500-bp elastase promoter element as described in the Materials and Methods.(B) Immunofluorescent membrane staining for TVA (green) in the acinar cells of the pancreas from a 4-month-old adult elastase- $t v-a$ mouse. Note absence of TVA staining in the islet (I) and duct $\left({ }^{\star}\right)$. Nuclei are stained with DAPI (blue). Original magnification 200×. (C) Identification of dividing cells in pancreases derived from 6-week-old adult (left) and 2-day-old (right) elastase-TVA mice by immunohistochemical staining for the proliferation marker Ki67. Original magnification 200×. (D) Immunofluorescent membrane staining for TVA (green) in pancreas of 2-day-old elastase $t v$ - $a$ transgenic (left) and nontransgenic (right) animals. Nuclei are stained with DAPI (blue). Original magnification 200x. (E) Coexpression of TVA (red) and Pdx1 (green) in the pancreas of a 2-day-old transgenic animal. TVA is present in cells within the islets identified by Pdx1 staining (arrow). Strong Pdx1 staining is also seen in some cells within the acinar compartment (arrowhead).

with anti-TVA and goat anti-Pdx1 antisera, as Pdx1 is found in pancreatic precursors and islet cells. We found that TVA was present on cells within islets, identified by the high levels of Pdx1 within the nuclei of islet cells (arrow, Fig. 2E), albeit at a lower level than was found in acini. However, TVA was not detected in cells within the ducts (data not shown). Further, we identified cells within acini (arrowhead, Fig. 2E) and ducts (data not shown) that were strongly positive for the presence of Pdx1. Thus, at this age, TVA is present in multiple cell types within the pancreas, reflecting either expression from the elastase promoter in several cell types or residual protein following expression in precursor cells during pancreatic development.

\section{Tumor induction by PyMT}

We initially sought to induce pancreatic tumors using RCAS vectors encoding mouse polyoma virus middle $\mathrm{T}$ antigen (PyMT). PyMT is a potent oncoprotein that interacts with c-Src and increases its protein kinase activity (Gottlieb and Villarreal 2001). PyMT also stimulates Ras-dependent and PI3 kinase-dependent signaling pathways that are activated in pancreatic carcinomas (Bardeesy and DePinho 2002). Production of PyMT in transgenic mice or through retroviral delivery leads to highly penetrant tumor formation in many tissues (Gottlieb and Villarreal 2001).

To maximize the fraction of proliferating and TVApositive cells within the pancreas susceptible to infection, we delivered RCAS virus producer cells intraperitoneally (IP) into 2-day-old elastase- $t v$ - $a$ transgenic mice. This approach, however, did not produce any grossly visible tumors in 15 animals through 13 mo of age. However, upon serial sectioning of harvested pancreases, 4 of the 15 animals were found to harbor small tumors (Table 1). These lesions displayed ductal morphology and most closely resembled pancreatic intraepithelial neoplasia 
Lewis et al.

Table 1. Tumor induction in elastase-tv-a mice

\begin{tabular}{lcc}
\hline RCAS Virus & TSG WT & Ink4a/Arf null \\
\hline PyMT & $4 / 15^{\mathrm{a}}$ & $8 / 11$ \\
c-myc & $0 / 15$ & $4 / 14$ \\
GFP & $0 / 13$ & $0 / 12$ \\
\hline
\end{tabular}

Elastase- $t v-a$ transgenic mice were injected on postnatal day 2 with DF1 cells producing the indicated viruses. Tumor suppressor gene (TSG) wild-type mice were sacrificed at 13 months of age. Ink4a/Arf null mice were sacrificed after development of lymphomas or sarcomas or at 7 months of age.

${ }^{a}$ Microscopic tumors identified upon serial sectioning of pancreases from injected mice. (TSG) Tumor suppressor gene.

(PanIN), a presumptive precursor to pancreatic ductal adenocarcinoma (Fig. 3C,D).

In hopes of increasing tumor incidence and shortening tumor latency, the elastase- $t v-a$ mice were crossed to Ink4a/Arf null mice. Inactivation of this locus occurs in the majority of human pancreatic ductal adenocarcinomas; however, Ink4a/Arf null mice do not spontaneously develop pancreatic carcinomas, although lympho- mas and sarcomas arise in $70 \%$ of these mice by 36weeks-of-age (Serrano et al. 1996). Delivery of RCASPyMT producer cells into 2-day old Ink4a/Arf null mice carrying the elastase- $t v-a$ transgene led to the formation of grossly visible tumors, detected after the sacrifice of lymphoma- or sarcoma-bearing animals between 4 and 6 months of age, in eight of 11 mice (Table 1).

Examination of histological sections obtained from the tumors demonstrated the presence of pancreatic lesions with various morphological features. Neoplasms with the cytologic features of acinar cells were visible in all eight tumor-bearing mice, and often were the largest lesions present within a pancreas (Fig. 3E,F). The acinar lesions ranged from microscopic clusters (atypical nodules) to grossly visible tumors. The lesions showed differing degrees of differentiation - some tumors had cells with granular, eosinophilic cytoplasm arranged in small nests and acinar formations, whereas other tumors were invasive carcinomas composed of poorly organized cells with cytoplasm devoid of zymogen granules. Ductal metaplasia, as determined by cellular morphology and staining for the transcription factor HNF1 $\beta$ (Table 2), $\mathbf{5 0 x}$

Figure 3. Histology of pancreatic lesions identified in elastase- $t v-a$ mice infected with RCAS-PyMT. Areas highlighted by yellow boxes are shown at higher magnification at right. $(A, B)$ Normal adult pancreas. $(C, D)$ PanIN lesion induced in a TSG wildtype mouse. Note shift from a flat cuboidal epithelium $(B)$ to a columnar epithelium with mucinous change $(D) .(E, F)$ Acinar carcinoma induced in an elastase-tv-a, Ink $4 a$ / Arf null mouse. Arrow indicates a non-neoplastic duct trapped within the tumor. $(G, H)$ Cystadenocarcinoma induced in an Ink4a/ Arf null mouse. Note papillary growth pattern of tumor cells into lumen of cyst and the prominent reactive stroma.
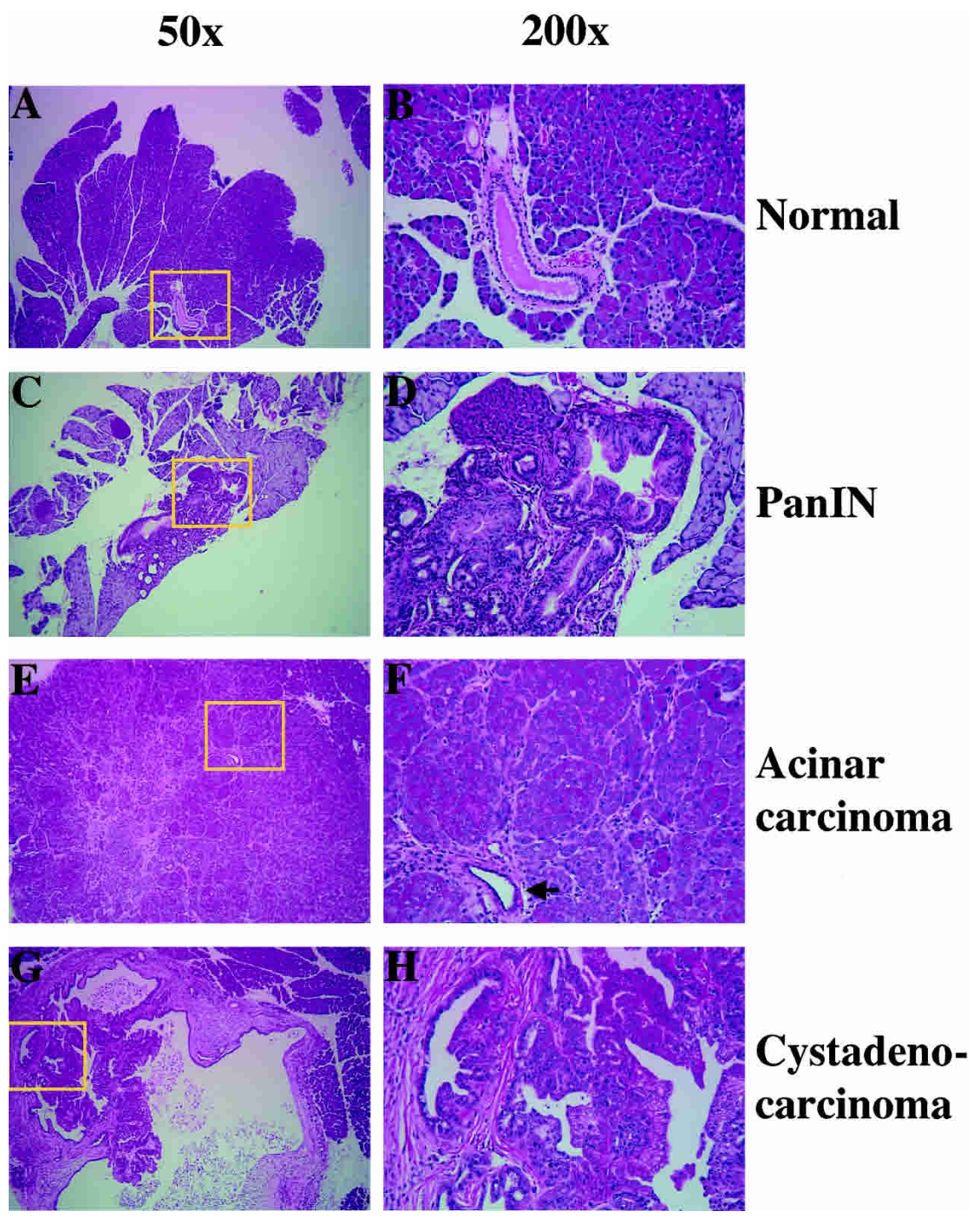
was absent in the majority of acinar tumors, and found only in association with reactive stroma. Trapped nonneoplastic ducts could occasionally be identified in invasive carcinomas (Fig. 3F). In addition to acinar tumors, ductal lesions - including cystic tumors with complex papillae and numerous glandular lumina (cystadenocarcinomas), and intraductal lesions with mucinous cytoplasm (PanIN lesions) similar to those seen in elastase$t v$ - $a$ mice - were also evident in seven of eight mice (Fig. $3 \mathrm{G}, \mathrm{H})$. In fact, multiple lesions of different histologic types were often present within a single pancreas. Abundant inflamed and cellular stroma, a characteristic of human pancreatic ductal neoplasms, was found associated with many of the ductal lesions (Fig. 3G,H; Hruban et al. 2002).

In contrast to the results with animals infected with RCAS-PyMT, no tumors were identified in 12 elastase$t v-a$, Ink $4 a / A r f$ null mice injected with DF1 cells producing RCAS-GFP, and sacrificed at 7 months of age, confirming that the tumors were not simply due to Ink4a/Arf deficiency and not likely due to insertional mutagenesis (Table 1).

To confirm that PyMT was expressed in the tumor cells, we performed in situ hybridizations with radiolabeled antisense PyMT RNA. PyMT RNA was readily detected in tumor cells, but not in infiltrating stromal or immune cells within the tumor (Fig. 4A, second and third panels). PyMT RNA was absent in the histologically normal sections of tumor-bearing pancreases and in pancreases from either uninfected mice or mice infected with RCAS-GFP (Fig. 4A, first panel; data not shown).

The presence of duct-like tubular structures containing acinar cells has been described previously in transgenic mouse models for pancreatic cancer (Jhappan et al. 1990; Sandgren et al. 1990; Wagner et al. 1998). We therefore sought to confirm the ductal nature of the lesions induced by PyMT. We stained pancreases from uninfected mice and tumor-bearing mice for the expression of keratin 19 , which is normally restricted to the ductal epithelium within the pancreas (Fig. 4B, first panel). As expected, PyMT-induced tumors with ductal appearance expressed keratin 19, confirming their ductal nature, whereas tumors with acinar features were negative for keratin 19 (Fig. 4B, second and third panels). The ductal tumors were also positive for the transcription factor HNF1 $\beta$, whose expression is predominantly restricted to ductal cells in the adult mouse pancreas (Table 2; Wilson et al. 2003).

\section{PyMT-induced tumors display features of progenitor cells}

The induction of ductal lesions by PyMT raised the possibility that either acinar-to-ductal transdifferentiation had occurred, as has been demonstrated previously in culture (De Lisle and Logsdon 1990) and proposed for transgenic models (Schmid 2002), or that an uncommitted or exocrine pancreas progenitor cell had been transformed by PyMT. To assess these possibilities, we stained the tumor lesions for the presence of the transcription factor Pdx1. Pdx1 is induced at embryonic day 9.5 in the mouse, coincident with the formation of the pancreatic bud, and therefore marks the earliest pancreatic progenitors (Edlund 2001). In the adult pancreas, Pdxl is restricted to the $\beta$ cells of the islets of Langerhans (Fig. 5A; Edlund 2001). As expected, Pdx1 was found only in the islets in the pancreases from uninfected animals, whereas $\mathrm{Pdx} 1$ was readily detected in the PyMT-induced pancreatic lesions irrespective of histologic type (Fig. 5B,C). Interestingly, Pdx1 was also detected in atypical acinar cell nodules, presumptive precursors to the acinar tumors, found in RCAS-PyMT-infected Ink4a/Arf null transgenic animals (Fig. 5D).

The high levels of Pdxl found in the PyMT-induced lesions suggested that either induction of $\mathrm{Pdx} 1$ is an early event in PyMT-induced transformation, or that the

Table 2. Expression of differentiation markers in RCAS-PyMT-and RCAS-c-myc-induced tumors

\begin{tabular}{|c|c|c|c|c|}
\hline $\begin{array}{l}\text { Differentiation } \\
\text { marker }\end{array}$ & Cell lineage & $\begin{array}{l}P y M T \text {-induced } \\
\text { acinar tumor }\end{array}$ & $\begin{array}{l}\text { PyMT-induced } \\
\text { ductal tumor }\end{array}$ & $\begin{array}{c}c-M y c \text {-induced } \\
\text { tumor }\end{array}$ \\
\hline Chymotrypsin & Acinar & + & - & - \\
\hline Mist1 & Acinar & - & - & - \\
\hline p48-PTF1 & Acinar & + & - & - \\
\hline Keratin 19 & Ductal & - & + & - \\
\hline HNF1 $\beta$ & Ductal & $-/+$ & + & - \\
\hline Pdx1 & Pancreas progenitor/endocrine & + & + & + \\
\hline Synaptophysin & Endocrine & + & + & + \\
\hline Pax6 & Endocrine & - & - & + \\
\hline Isl1 & Endocrine & - & - & + \\
\hline Nkx 2.2 & Endocrine & - & - & + \\
\hline Insulin & $\beta$-cell & - & - & + \\
\hline Glucagon & $\alpha$-cell & - & - & - \\
\hline Somatostatin & $\delta$-cell & - & - & - \\
\hline
\end{tabular}

Expression determined by immunohistochemistry.

$(-)$ Absent in all tumors.

$(+)$ Present in all tumors.

$(-/+)$ Present in some tumors. 
Lewis et al.

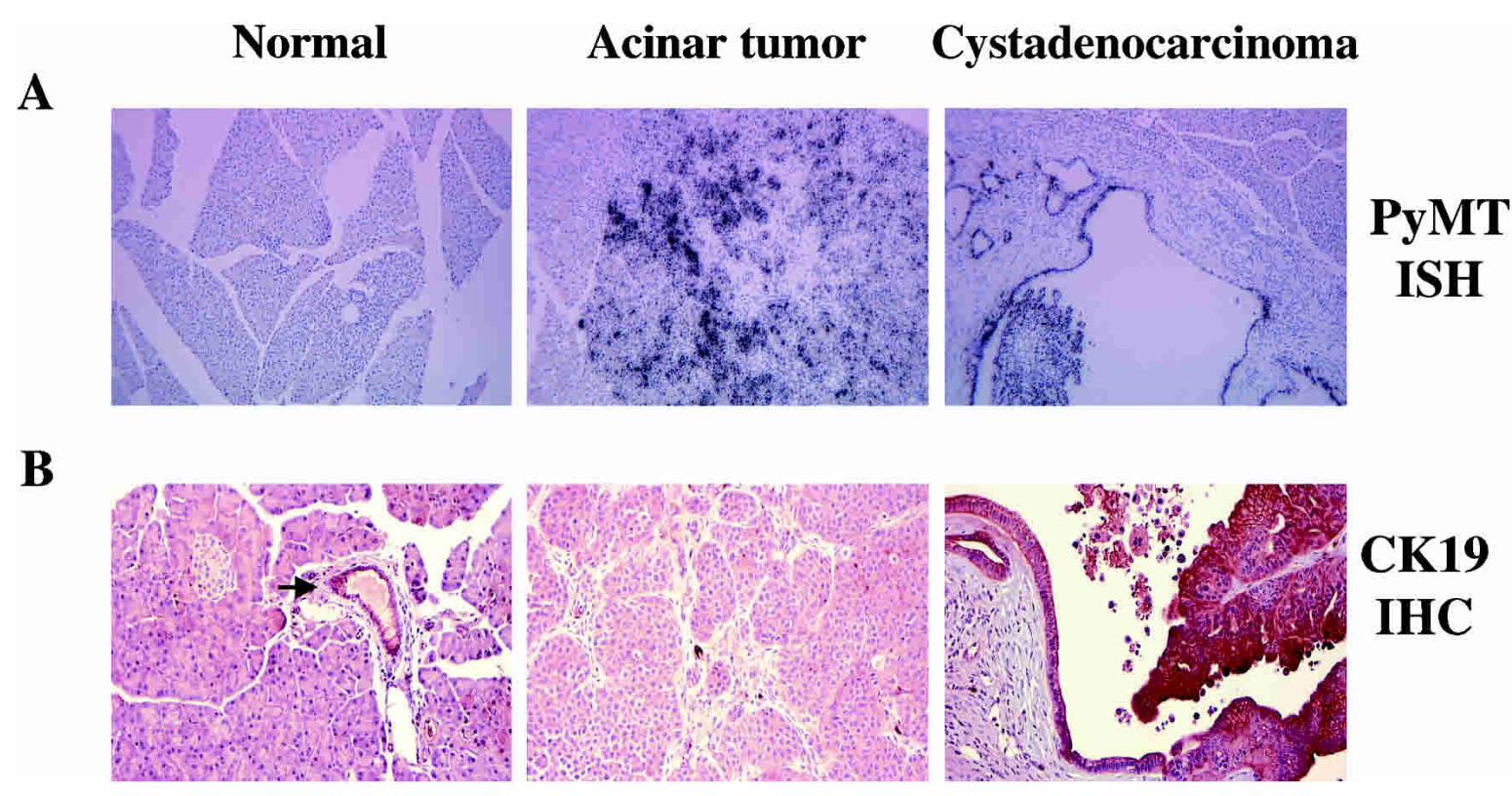

Figure 4. (A) Detection of PyMT RNA in induced pancreatic tumors by in situ hybridization. A ${ }^{33}$ P-labeled PyMT antisense RNA probe was hybridized to pancreases from a RCAS-GFP-infected animal (left), a RCAS-PyMT-induced acinar tumor (middle), and a RCAS-PyMT-induced cystadenocarcinoma (right). Note absence of PyMT expression in reactive stroma in the ductal lesion (right). Original magnification 100×. (B) Detection of keratin 19 specifically in RCAS-PyMT-induced tumors with ductal morphology. Immunohistochemistry against keratin 19 demonstrates expression restricted to ductal epithelium in a normal pancreas (arrow, left). In PyMT-induced tumors, keratin 19 is detected in tumors with ductal morphology (right), but not tumors with acinar morphology (middle). Original magnification $200 \times$.

target cell for transformation contained high levels of Pdx1, a marker for pancreatic progenitor cells. To further explore this second possibility, we next stained the pan- creatic lesions for the expression of chymotrypsin and synaptophysin, which identify cells of the acinar and endocrine compartments, respectively. Both acinar tumors

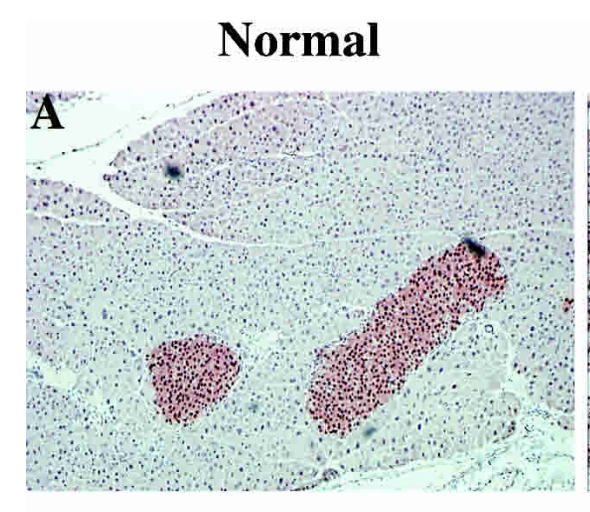

Figure 5. Detection of $\mathrm{Pdx} 1$ expression in RCAS-PyMT-induced tumors. In the normal adult pancreas, $\mathrm{Pdx} 1$ expression is restricted to the $\beta$-cells of the islets of Langerhans $(A)$. RCAS-PyMT-induced ductal $(B)$ and acinar $(C)$ tumors express Pdx1. Early atypical nodules induced by PyMT also express Pdx1 (arrows, D). Original magnification $200 \times$.
Acinar carcinoma

\section{Cystadenocarcinoma}

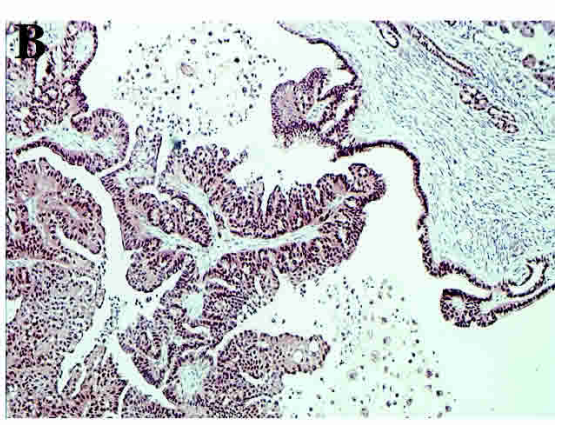

Atypical nodule
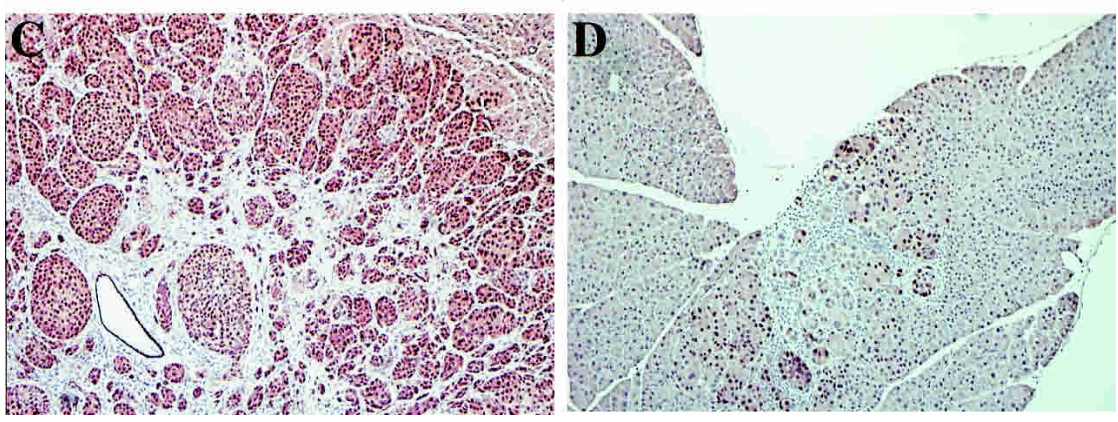
and atypical nodules were uniformly positive for both markers (Fig. 6B,C, first and second panels), whereas the ductal lesions were negative for chymotrypsin and had scattered synaptophysin positive cells (Fig. 6B,C, third panels). Together, these data demonstrate that RCASPyMT-induced tumors are composed of cells that express progenitor markers, as well as markers for multiple differentiated lineages.

To determine whether the PyMT-induced tumors expressed other endocrine markers, we stained tumor sections for several transcription factors specific to either acinar or endocrine cells. The endocrine-specific transcription factors Isl1, Pax6, and Nkx2.2 were not detected (Table 2; Edlund 1998). Furthermore, acinar tumors, but not ductal tumors, were positive for PTF1-p48, a transcription factor found in acinar, but not ductal, cells in the normal adult pancreas (Table 2; Edlund 1998).

\section{c-Myc induces insulinomas in elastase-tv-a mice}

To ascertain whether the induced tumor type in elastase$t v-a$ transgenic mice is dependent on the nature of the initiating oncogene, we infected mice with DF1 cells producing RCAS-c-myc, again, by IP injection $2 \mathrm{~d}$ after birth. Mice, wild type at tumor suppressor gene loci, did not develop tumors through 13 months of age (Table 1).
However, tumors were detected in 4 of 14 elastase- $t v-a$ transgenic, Ink4a/Arf null mice injected with RCAS-c$m y c$ and sacrificed at 7 months of age (Table 1). Histologically, RCAS-c-myc-induced tumors closely resembled well-differentiated human pancreatic endocrine tumors (Fig. 7A). The tumors have a low proliferation rate, as determined by Ki67 staining (data not shown), similar to the low proliferation rate seen in human pancreatic endocrine tumors (Mazzaferri and O'Dorisio 1987; Pelosi et al. 1996). To confirm that these tumors were induced by RCAS-c-myc, we performed in situ hybridizations to detect human c-myc RNA within the tumors. All tumors were positive for human c-myc RNA, whereas pancreases from mice infected with RCAS-GFP were negative (Fig. 7B). Additionally, we identified RCAS DNA by PCR amplification of ALSV sequences from genomic DNA isolated from tumor sections (data not shown).

To confirm that the c-Myc-induced tumors were composed of cells with properties of pancreatic endocrine cells, we stained sections for the presence of lineagespecific markers. All tumors were positive for synaptophysin, an endocrine marker (Fig. 8A), and negative for chymotrypsin, an exocrine marker (Fig. 8B). The tumors are composed of $\beta$-cells as determined by the presence of insulin, and the absence of the hormones glucagon and

\section{Acinar Tumor}

A

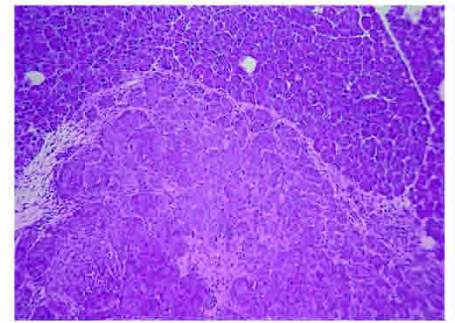

B

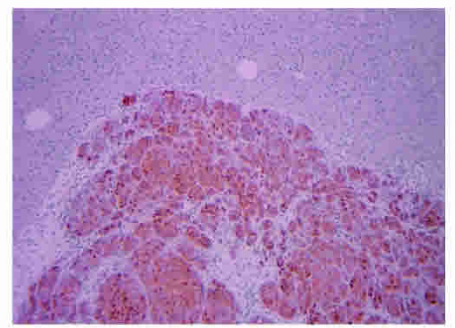

C

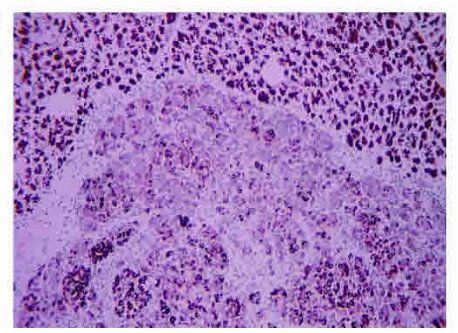

\section{Atypical nodule Cystadenocarcinoma}
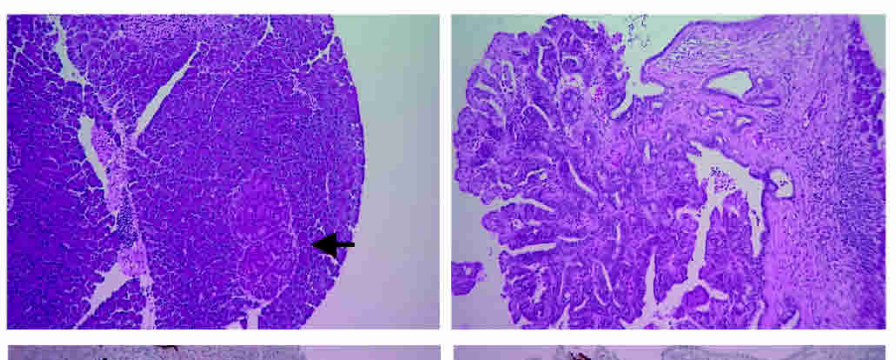

H\&E
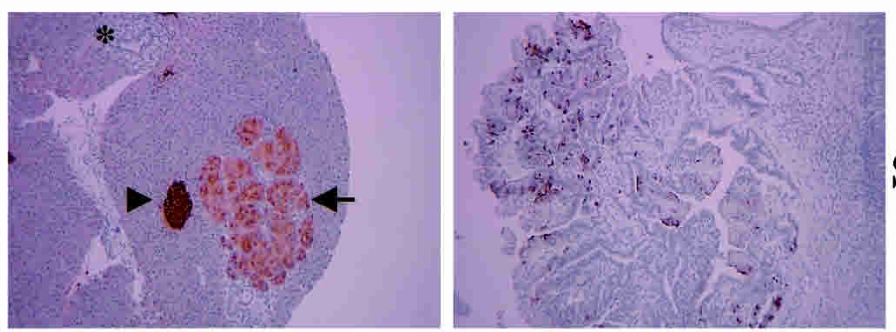

Synaptophysin
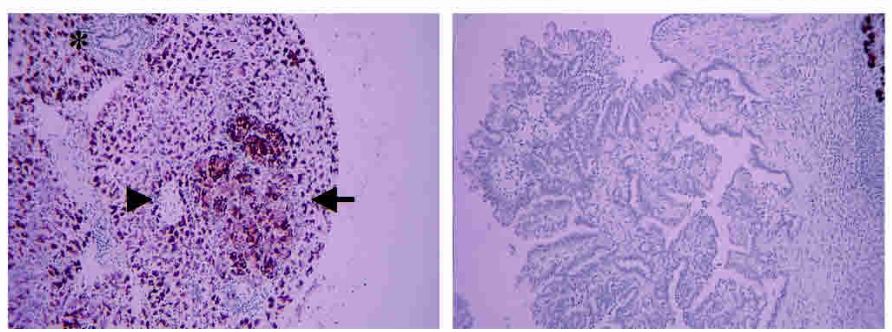

Figure 6. RCAS-PyMT-induced tumors express synaptophysin. (A) Hematoxylin and eosin stain of RCAS-PyMT-induced acinar carcinoma (left), atypical acinar nodule (arrow, middle), and cystadenocarcinoma (right). Immunohistochemical detection of synaptophysin $(B)$, and chymotrypsin $(C)$. Arrowheads indicate islets and asterisks indicate normal pancreatic ducts. Original magnification $100 \times$. 
Lewis et al.

Figure 7. RCAS-c-myc induces insulinomas. (A) Histology of RCAS-c-myc-induced tumors at $25 \times$ magnification (left) and 400x magnification (right). Note prominent nucleoli, and absence of mitotic figures. Arrow at left indicates a normal islet. (B) Detection of human $c$-myc RNA by in-situ hybridization with a ${ }^{33} \mathrm{P}$ labeled antisense RNA probe in an RCAS$c$-myc induced tumor (right), but not in surrounding acinar tissue or in the pancreas from an animal infected with RCASGFP (left). Original magnification 100x.
A

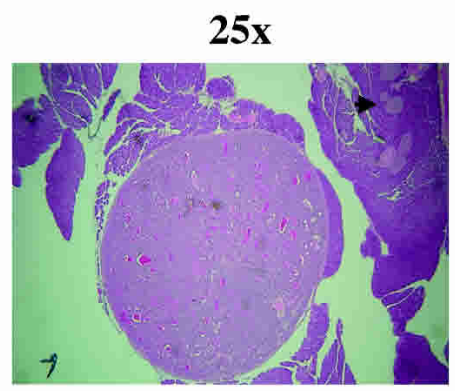

B

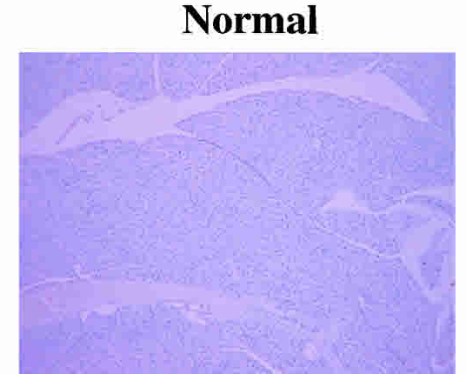

$400 x$

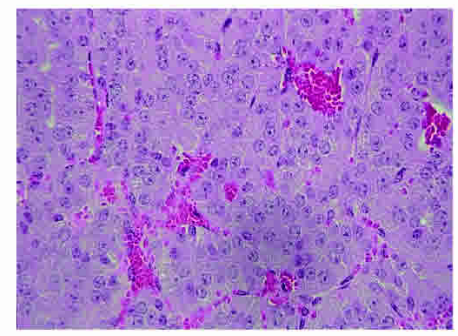

Endocrine tumor

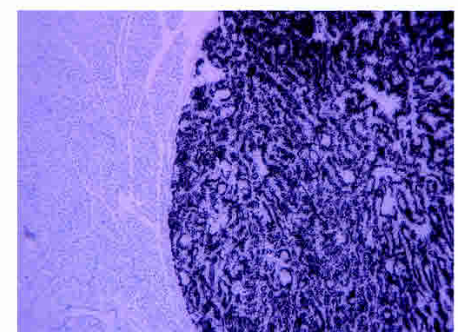

H\&E

c-myc ISH somatostatin, which are produced by the $\alpha$ - and $\delta$-cells of the islets respectively (Table 2). Further, Pdx1 and the endocrine-specific transcription factors Is11, Nkx2.2, and Pax6 were detected in the c-Myc-induced tumors, consistent with their endocrine status (Fig. 8C,D; Table 2). The acinar-specific transcription factors PTF1-p48 and Mist1 were not detected in the tumors (Fig. 8E; Table 2; Edlund 1998; Pin et al. 2000). Together, these data demonstrate that infection of elastase- $t v-a$, Ink $4 a / A r f$ null mice with RCAS-c-myc induces the formation of pancreatic endocrine tumors.

\section{Discussion}

We have generated a new mouse model for pancreatic cancer through the somatic introduction of oncogenes using the RCAS-TVA gene delivery system. This system uses avian leukosis sarcoma virus-based vectors to deliver genes to cells made susceptible to infection by transgenic expression of the ALSV-A receptor TVA under the regulation of the pancreas-specific elastase promoter. This model offers the advantage of somatic oncogene delivery at a defined time, and eliminates the possibility of embryonic expression of transforming oncogenes. In addition, only a subset of cells within an organ are infected and there is no viral spread. Therefore, tumors arise from cells that are surrounded by uninfected, and normal neighbors. Further, this technology allows the analysis of the effects of different oncogenes with a single transgenic line by performing infections with vectors encoding different oncogene products.

Delivery of RCAS viruses encoding the PyMT and cMyc oncoproteins led to strikingly different results. PyMT induced tumors with the histologic features of either acinar or ductal cells. These tumors express the pancreatic progenitor cell marker Pdx1, as well as markers for multiple cell lineages. In contrast, c-Myc exclusively induced tumors with the features of pancreatic endocrine neoplasms. These tumors express pancreatic $\beta$-cell-specific markers and resemble human insulinomas in several ways, including a low proliferation rate (Mazzaferri and O'Dorisio 1987; Pelosi et al. 1996).

The induction of different tumor types by PyMT and $\mathrm{c}-\mathrm{Myc}$ raises interesting questions about the cell of origin of pancreatic cancers. Given the presence of detectable TVA on the surface of multiple cell types and the large number of dividing cells within the pancreases of newborn mice, it is likely that cells at different developmental stages are infected by the RCAS viruses. Thus, it is unclear whether PyMT and c-Myc transform the same target cell and guide it toward different fates, or whether they transform different progenitor cells already committed to specific cell fates. The definitive identification of the target cell(s) in our model will require the development of improved markers for pancreatic progenitor cells. Whereas we believe that the tumors observed in our model are derived from the transformation of immature pancreatic cells, it is possible that the tumor types observed in our model could result from the dedifferentiation or transdifferentiation of more mature cells.

Our experimental approach, by its nature, requires that tumors be derived from actively dividing cells, which may create a bias toward the transformation of cells that retain progenitor capacity. It will be interesting to determine whether somatic introduction of oncogenes into nondividing cells in the adult pancreas will cause the induction of tumors, and what the histologic nature of tumors induced by PyMT and c-Myc will be if they do arise from nondividing cells. We have recently described a mechanism for performing such experiments using 


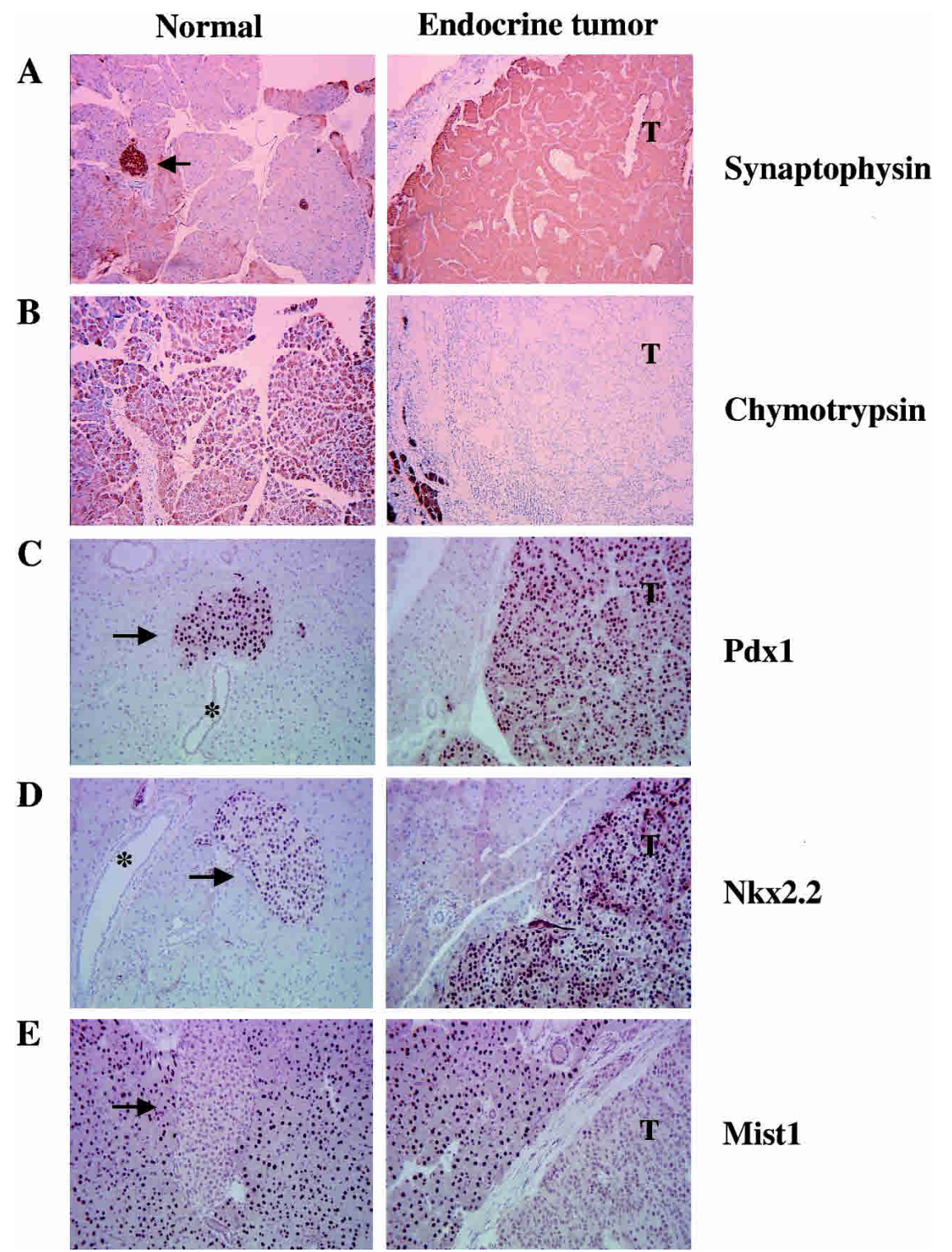

HIV-based vectors pseudotyped with the ALSV-A envelope protein that have the ability to infect nondividing cells (Lewis et al. 2001).

In a provocative series of experiments, Yoshida and Hanahan demonstrated that islets isolated from juvenile mice and infected with retroviruses encoding PyMT gave rise exclusively to ductal adenocarcinomas after transplantation into syngeneic hosts (Yoshida and Hanahan 1994). Interestingly, they were unable to obtain tumors if the islets were isolated from adult mice. These experiments suggested that progenitor cells, present in the islets of juvenile mice but not adults, were capable of being transformed into ductal cell tumors by PyMT.

The appearance of acinar cell carcinomas after RCASPyMT infection of elastase- $t v-a, \operatorname{Ink} 4 a /$ Arf null mice is consistent with findings in previously described transgenic models, in which the elastase promoter was utilized to drive the expression of various oncogenes (Or- nitz et al. 1987; Quaife et al. 1987; Sandgren et al. 1991). However, almost all tumor-bearing mice (7/8) also had tumors with ductal morphologies, and which expressed duct-specific markers. Interestingly, delivery of RCASPyMT to elastase- $t v-a$ mice wild type at the Ink $4 a / A r f$ locus led exclusively to the formation of ductal lesions. This finding suggests the possibility that PyMT expression, and the consequent activation of Ras-signaling pathways downstream, preferentially transforms cells along the ductal lineage, as occurs in human pancreatic tumors with $K-R A S$ mutations (Bardeesy and DePinho 2002). The absence of the Ink4a/Arf locus in elastase$t V-a$ transgene-bearing mice presumably provides a permissive environment for transformation along the acinar cell lineage as well.

The induction of ductal lesions has also been described in elastase- $c-m y c$, elastase-K-ras, and elastase-TGF- $\alpha$ transgenic models, although, in these transgenic models, 
the expression of the transgene in the ductal lesions was not demonstrated (Sandgren et al. 1990, 1991; Wagner et al. 1998, 2001; Grippo et al. 2003). Here, we demonstrate that PyMT is expressed in the ductal lesions and presumably plays a direct role in the development of these lesions.

In the previous transgenic models, it was proposed that acinar cells transdifferentiated into ductal cells, on the basis of the presence of tubular structures in which individual cells within the structure expressed either acinar or ductal markers (Sandgren et al. 1990, 1991; Wagner et al. 1998, 2001). We did not find evidence for the existence of similar tubular structures within the pancreases of mice bearing PyMT-induced tumors, and thus, the ductal lesions within these pancreases appear to arise de novo. Mucinous changes in the epithelial cells in the ductal lesions closely resemble those of PanIN, a lesion recognized as a ductal adenocarcinoma precursor. The presence of de novo ductal lesions, and the widespread presence of TVA in the pancreases of newborn mice, suggests that the tumors might be derived from pancreatic progenitors, rather than mature acinar cells, consistent with our other findings.

Our findings with c-Myc contrast with findings reported earlier in elastase-c-myc transgenic mice, in which no endocrine lesions were identified (Sandgren et al. 1991). However, this discrepancy can be at least partly reconciled in light of the recent findings of Pelengaris and colleagues (Pelengaris et al. 2002). In their work, induction of c-Myc expression in pancreatic $\beta$-cells led to the rapid induction of $\beta$-cell apoptosis and the involution of all islets. However, if apoptosis is suppressed, c-Myc rapidly induces $\beta$-cell tumors. In our model, tumors are induced in the absence of the Ink $4 a / A r f$ locus, which has been shown to be required for c-Myc induced apoptosis (Eischen et al. 1999; Schmitt et al. 1999; G. Evan, pers. comm.). Thus, the absence of endocrine tumors in the elastase-c-myc transgenic model reported by Sandgren and colleagues probably resulted either from the apoptotic death of any cells entering the $\beta$-cell lineage following deregulated expression of $c-m y c$, or from the absence of sustained $c-m y c$ gene expression in cells in the $\beta$-cell lineage. In our model, oncogene expression is driven by the viral LTR and is not dependent on cell type or differentiation status. The absence of exocrine tumors in RCAS-c-myc-infected animals suggests that c-Myc preferentially transforms cells along the $\beta$-cell lineage, although with adequate levels of expression it appears to induce exocrine pancreatic tumors as well.

Despite the congruence of our findings with those of Pelengaris and colleagues (Pelengaris et al. 2002), it should be noted that the tumors induced by c-Myc in the two models differ in their proliferation rates and invasiveness. These differences may reflect the acute and widespread induction of high levels of c-Myc protein in islet cells achieved by Pelengaris et al. (2002).

In summary, the approach to pancreatic carcinogenesis that we have described here should also be useful in the dissection of the mechanisms that underlie the development of specific pancreatic cancer types in human patients. For example, mutated KRAS and $\beta$-catenin are associated specifically with ductal and acinar carcinomas, respectively, and the effects of such genes introduced somatically to TVA transgenic mice with RCAS vectors should help to determine the basis for these associations.

\section{Materials and methods}

\section{Transgenic mice and animal care}

The elastase- $t v-a$ transgene was constructed in pbluescript $\mathrm{SK}(+)$ by placing a 500 -bp HindIII/BamHI rat elastase promoter fragment encompassing nucleotides -500 to +8 (gift of Ray MacDonald) proximal to a $1.2-\mathrm{kb}$ BamHI fragment containing the 800-bp $t v-a$ cDNA fused to SV40 intron and polyadenylation sequences (gift of G. Fisher, NIH; Bates et al. 1993; Kruse et al. 1993). The 1.7-kb transgene was isolated from vector sequences by digestion with XhoI and XbaI, gel purified, and resuspended in TE for injection into pronuclei from FVB mice. Animals were kept in specific pathogen-free housing with abundant food and water under guidelines approved by the MSKCC Institutional Animal Care and Use Committee and Research Animal Resource Center.

\section{Virus delivery}

The RCAS-GFP, RCAS-PyMT, and RCAS-c-myc vectors have been described previously (Holland et al. 2000; Fults et al. 2002; Orsulic et al. 2002). DF1 chicken fibroblasts (Himly et al. 1998; Schaefer-Klein et al. 1998) transfected with RCAS vectors were maintained in DMEM supplemented with $10 \%$ FBS in humidified $37^{\circ} \mathrm{C}$ incubators under $5 \% \mathrm{CO}_{2}$. Cells to be injected were harvested, washed once with PBS, and resuspended in PBS at a final concentration of $10^{7}$ cells $/ \mathrm{mL}$. A total of $100 \mu \mathrm{L}$ of the cell suspension was delivered IP to 2-day-old animals using syringes attached with 27-gauge needles.

\section{Tumor harvest and histology}

Animals were sacrificed with a lethal dose of $\mathrm{CO}_{2}$ as per institutional guidelines. Pancreases were removed and either fixed in $10 \%$ buffered formalin overnight at room temperature or snap frozen in liquid nitrogen. Fixed tissues were paraffin embedded and 5 - $\mu \mathrm{m}$ sections placed on sialynated slides at Histoserv Inc.

\section{Immunohistochemistry}

Paraffin sections were deparaffinized and rehydrated by passage through Clear-Rite 3 and a graded alcohol series. Endogenous peroxidase activity was inactivated by treatment with $3 \%$ hydrogen peroxide, after which antigen retrieval was performed utilizing heated citric buffer. Slides were blocked for $1 \mathrm{~h}$, and then incubated with primary antibody at room temperature for $1 \mathrm{~h}$. After washing with PBS, slides were incubated with secondary antibody according to the manufacturer's instructions (Vector Labs). Substrate incubation and color development were performed according to the manufacturer's instructions (Vector Labs). Primary antibodies used were rabbit anti-Ki67 (Novocastra) 1:1000; mouse anti-human keratin 19 (Abcam) 1:50; rabbit anti-mouse Pdx1 (gift of Chris Wright) 1:5000; mouse anti-rat PTF1-p48 (gift of Ray MacDonald) 1:100; mouse anti-Isl1 (Developmental Studies Hybridoma Bank, University of Iowa) 1: 
100; mouse anti-Nkx2.2 (Developmental Studies Hybridoma Bank, University of Iowa) 1:200; rabbit anti-mouse Mist1 (gift of Steve Konieczny) 1:500; rabbit anti-Pax6 (Covance) 1:200; rabbit anti-bovine insulin (Immunostar) 1:100; rabbit anti-human somatostatin (DAKO) 1:200; rabbit anti-human glucagon (DAKO) 1:100; and rabbit anti-human synaptophysin 1:1000 (DAKO). For chymotrypsin staining, instead of citric buffer incubation, slides were pretreated with $0.05 \mu \mathrm{g} / \mathrm{mL}$ protease 24 (Sigma) for $10 \mathrm{~min}$ at $37^{\circ} \mathrm{C}$. Sheep antihuman chymotrypsin antibody (Biodesign International) was incubated at $4^{\circ} \mathrm{C}$ overnight at a dilution of $1: 20,000$.

\section{Immunofluorescence}

Paraffin-embedded sections were rehydrated, and antigen retrieval performed as described above. After blocking, slides were incubated with primary antibodies overnight at $4^{\circ} \mathrm{C}$. After three washes with PBS, slides were incubated with secondary antibodies overnight at $4^{\circ} \mathrm{C}$. Slides were then washed with PBS and counterstained with DAPI to identify nuclei. Primary antibodies used were rabbit anti-TVA (gift of Andrew Leavitt) 1:200; mouse anti-Ki67 (Novocastra) 1:100; and goat anti-mouse Pdx1 (gift of Chris Wright) 1:2000. Secondary antibodies, used at a 1:200 dilution, were obtained from Jackson Immunoresearch Laboratories.

\section{In situ hybridization}

Freshly generated paraffin sections were rehydrated as described above. After blocking for $3 \mathrm{~h}$ in prehybridization solution (Lehnert and Akhurst 1988), slides were hybridized to $4 \times 10^{6}$ cpm of ${ }^{33}$ P-labeled antisense RNA probes specific for either PyMT or human c-myc. Washes were performed as described previously (Wilkinson et al. 1987). Slides were then dipped in warm photographic emulsion and exposed for 2 wk before development.

\section{Acknowledgments}

We thank the NHGRI transgenic core for the generation of elastase-TVA mice; Mary Barrett, Jennifer Doherty, and Irina Linkov for technical assistance; the MSKCC Molecular Cytology Core for assistance with in-situ hybridization; Ray MacDonald (University of Texas, Southwestern, Dallas) for the elastase promoter fragment; Chris Wright (Vanderbilt University, Nashville, TN), Andy Leavitt (University of California, San Francisco), Steve Konieczny (Purdue University, West Lafayette, IN), and Ray MacDonald for gifts of antibodies; and Eric Holland, Kirsten Hubbard, and members of the Varmus lab for discussion and critical reading of the manuscript. B.C.L. was supported by a Helen Hay Whitney Foundation postdoctoral fellowship and a Career Award in the Biomedical Sciences from the Burroughs Wellcome Fund.

The publication costs of this article were defrayed in part by payment of page charges. This article must therefore be hereby marked "advertisement" in accordance with 18 USC section 1734 solely to indicate this fact.

\section{References}

Abraham, S.C., Wu, T.T., Hruban, R.H., Lee, J.H., Yeo, C.J., Conlon, K., Brennan, M., Cameron, J.L., and Klimstra., D.S. 2002. Genetic and immunohistochemical analysis of pancreatic acinar cell carcinoma: Frequent allelic loss on chromo- some $11 \mathrm{p}$ and alterations in the APC/ $\beta$-catenin pathway. Am. J. Pathol. 160: 953-962.

Bardeesy, N. and DePinho, R.A. 2002. Pancreatic cancer biology and genetics. Nat. Rev. Cancer 2: 897-909.

Bates, P., Young, J.A., and Varmus, H.E. 1993. A receptor for subgroup A Rous sarcoma virus is related to the low density lipoprotein receptor. Cell 74: 1043-1051.

De Lisle, R.C. and Logsdon, C.D. 1990. Pancreatic acinar cells in culture: Expression of acinar and ductal antigens in a growth-related manner. Eur. J. Cell. Biol. 51: 64-75.

Edlund, H. 1998. Transcribing pancreas. Diabetes 47: 1817-1823.

- 2001. Developmental biology of the pancreas. Diabetes 50: S5-S9.

- 2002. Pancreatic organogenesis-developmental mechanisms and implications for therapy. Nat. Rev. Genet. 3: 524532.

Eischen, C.M., Weber, J.D., Roussel, M.F., Sherr, C.J., and Cleveland, J.L. 1999. Disruption of the ARF-Mdm2-p53 tumor suppressor pathway in Myc-induced lymphomagenesis. Genes \& Dev. 13: 2658-2669.

Fisher, G.H., Orsulic, S., Holland, E., Hively, W.P., Li, Y., Lewis, B.C., Williams, B.O., and Varmus, H.E. 1999. Development of a flexible and specific gene delivery system for production of murine tumor models. Oncogene 18: 5253-5260.

Fults, D., Pedone, C., Dai, C., and Holland, E.C. 2002. MYC expression promotes the proliferation of neural progenitor cells in culture and in vivo. Neoplasia 4: 32-39.

Gottlieb, K.A. and Villarreal, L.P. 2001. Natural biology of polyomavirus middle T antigen. Microbiol. Mol. Biol. Rev. 65: 288-318.

Grippo, P.J., Nowlin, P.S., Demeure, M.J., Longnecker, D.S., and Sandgren, E.P. 2003. Preinvasive pancreatic neoplasia of ductal phenotype induced by acinar cell targeting of mutant kras in transgenic mice. Cancer Res. 63: 2016-2019.

Gu, G., Dubauskaite, J., and Melton, D.A. 2002. Direct evidence for the pancreatic lineage: NGN3+ cells are islet progenitors and are distinct from duct progenitors. Development 129: 2447-2457.

Himly, M., Foster, D.N., Bottoli, I., Iacovoni, J.S., and Vogt, P.K. 1998. The DF-1 chicken fibroblast cell line: Transformation induced by diverse oncogenes and cell death resulting from infection by avian leukosis viruses. Virology 248: 295-304.

Holland, E.C., Li, Y., Celestino, J., Dai, C., Schaefer, L., Sawaya, R.A., and Fuller, G.N. 2000. Astrocytes give rise to oligodendrogliomas and astrocytomas after gene transfer of polyoma virus middle T antigen in vivo. Am. J. Pathol. 157: 10311037.

Hruban, R.H., Yeo, C.J., and Kern, S.E. 2002. Pancreatic cancer. In The genetic basis of human cancer (eds. B. Vogelstein and K.W. Kinzler), pp. 659-675. McGraw-Hill, New York.

Jaffee, E.M., Hruban, R.H., Canto, M., and Kern, S.E. 2002. Focus on pancreas cancer. Cancer Cell 2: 25-28.

Jemal, A., Thomas, A., Murray, T., and Thun, M. 2002. Cancer statistics, 2002. CA Cancer J. Clin. 52: 23-47.

Jhappan, C., Stahle, C., Harkins, R.N., Fausto, N., Smith, G.H., and Merlino, G.T. 1990. TGF $\alpha$ overexpression in transgenic mice induces liver neoplasia and abnormal development of the mammary gland and pancreas. Cell 61: 1137-1146.

Jonsson, J., Carlsson, L., Edlund, T., and Edlund, H. 1994. Insulin-promoter-factor 1 is required for pancreas development in mice. Nature 371: 606-609.

Kawaguchi, Y., Cooper, B., Gannon, M., Ray, M., MacDonald, R.J., and Wright, C.V. 2002. The role of the transcriptional regulator Ptfla in converting intestinal to pancreatic progenitors. Nat. Genet. 32: 128-134. 
Klimstra, D.S., Rosai, J., and Heffess, C.S. 1994. Mixed acinarendocrine carcinomas of the pancreas. Am. J. Surg. Pathol. 18: $765-778$.

Kruse, F., Rose, S.D., Swift, G.H., Hammer, R.E., and MacDonald, R.J. 1993. An endocrine-specific element is an integral component of an exocrine-specific pancreatic enhancer. Genes \& Dev. 7: 774-786.

Lehnert, S.A. and Akhurst, R.J. 1988. Embryonic expression pattern of TGF $\beta$ type-1 RNA suggests both paracrine and autocrine mechanisms of action. Development 104: 263-273.

Lewis, P.F. and Emerman, M. 1994. Passage through mitosis is required for oncoretroviruses but not for the human immunodeficiency virus. J. Virol. 68: 510-516.

Lewis, B.C., Chinnasamy, N., Morgan, R.A., and Varmus, H.E. 2001. Development of an avian leukosis-sarcoma virus subgroup A pseudotyped lentiviral vector. J. Virol. 75: 93399344.

Mazzaferri, E.L. and O'Dorisio, T.M. 1987. Endocrine tumorsspecial problems in diagnosis and management. Semin. Oncol. 14: 235-236.

Miller, D.G., Adam, M.A., and Miller, A.D. 1990. Gene transfer by retrovirus vectors occurs only in cells that are actively replicating at the time of infection. Mol. Cell. Biol. 10: 42394242.

Offield, M.F., Jetton, T.L., Labosky, P.A., Ray, M., Stein, R.W., Magnuson, M.A., Hogan, B.L., and Wright, C.V. 1996. PDX-1 is required for pancreatic outgrowth and differentiation of the rostral duodenum. Development 122: 983-995.

Ornitz, D.M., Palmiter, R.D., Hammer, R.E., Brinster, R.L., Swift, G.H., and MacDonald, R.J. 1985. Specific expression of an elastase-human growth hormone fusion gene in pancreatic acinar cells of transgenic mice. Nature 313: 600-602.

Ornitz, D.M., Hammer, R.E., Messing, A., Palmiter, R.D., and Brinster, R.L. 1987. Pancreatic neoplasia induced by SV40 T-antigen expression in acinar cells of transgenic mice. Science 238: 188-193.

Orsulic, S. 2002. An RCAS-TVA-based approach to designer mouse models. Mamm. Genome 13: 543-547.

Orsulic, S., Li, Y., Soslow, R.A., Vitale-Cross, L.A., Gutkind, J.S., and Varmus, H.E. 2002. Induction of ovarian cancer by defined multiple genetic changes in a mouse model system. Cancer Cell 1: 53-62.

Pelengaris, S., Khan, M., and Evan, G.I. 2002. Suppression of Myc-induced apoptosis in $\beta$ cells exposes multiple oncogenic properties of Myc and triggers carcinogenic progression. Cell 109: 321-334.

Pelosi, G., Bresaola, E., Bogina, G., Pasini, F., Rodella, S., Castelli, P., Iacono, C., Serio, G., and Zamboni, G. 1996. Endocrine tumors of the pancreas: Ki-67 immunoreactivity on paraffin sections is an independent predictor for malignancy: A comparative study with proliferating-cell nuclear antigen and progesterone receptor protein immunostaining, mitotic index, and other clinicopathologic variables. Hum. Pathol. 27: 1124-1134.

Pin, C.L., Bonvissuto, A.C., and Konieczny, S.F. 2000. Mist1 expression is a common link among serous exocrine cells exhibiting regulated exocytosis. Anat. Rec. 259: 157-167.

Quaife, C.J., Pinkert, C.A., Ornitz, D.M., Palmiter, R.D., and Brinster, R.L. 1987. Pancreatic neoplasia induced by ras expression in acinar cells of transgenic mice. Cell 48: 10231034.

Roe, T., Reynolds, T.C., Yu, G., and Brown, P.O. 1993. Integration of murine leukemia virus DNA depends on mitosis. EMBO J. 12: 2099-2108.

Sandgren, E.P., Luetteke, N.C., Palmiter, R.D., Brinster, R.L., and Lee, D.C. 1990. Overexpression of TGF $\alpha$ in transgenic mice: Induction of epithelial hyperplasia, pancreatic metaplasia, and carcinoma of the breast. Cell 61: 1121-1135.

Sandgren, E.P., Quaife, C.J., Paulovich, A.G., Palmiter, R.D., and Brinster, R.L. 1991. Pancreatic tumor pathogenesis reflects the causative genetic lesion. Proc. Natl. Acad. Sci. 88: 93-97.

Schaefer-Klein, J., Givol, I., Barsov, E.V., Whitcomb, J.M., VanBrocklin, M., Foster, D.N., Federspiel, M.J., and Hughes, S.H. 1998. The EV-O-derived cell line DF-1 supports the efficient replication of avian leukosis-sarcoma viruses and vectors. Virology 248: 305-311.

Schmid, R.M. 2002. Acinar-to-ductal metaplasia in pancreatic cancer development. J. Clin. Invest. 109: 1403-1404.

Schmitt, C.A., McCurrach, M.E., de Stanchina, E., Wallace-Brodeur, R.R., and Lowe, S.W. 1999. INK4a/ARF mutations accelerate lymphomagenesis and promote chemoresistance by disabling p53. Genes \& Dev. 13: 2670-2677.

Schwitzgebel, V.M., Scheel, D.W., Conners, J.R., Kalamaras, J., Lee, J.E., Anderson, D.J., Sussel, L., Johnson, J.D., and German, M.S. 2000. Expression of neurogenin3 reveals an islet cell precursor population in the pancreas. Development 127: 3533-3542.

Serrano, M., Lee, H., Chin, L., Cordon-Cardo, C., Beach, D., and DePinho, R.A. 1996. Role of the INK4a locus in tumor suppression and cell mortality. Cell 85: 27-37.

Wagner, M., Luhrs, H., Kloppel, G., Adler, G., and Schmid, R.M. 1998. Malignant transformation of duct-like cells originating from acini in transforming growth factor transgenic mice. Gastroenterology 115: 1254-1262.

Wagner, M., Greten, F.R., Weber, C.K., Koschnick, S., Mattfeldt, T., Deppert, W., Kern, H., Adler, G., and Schmid, R.M. 2001. A murine tumor progression model for pancreatic cancer recapitulating the genetic alterations of the human disease. Genes \& Dev. 15: 286-293.

Wilkinson, D.G., Bailes, J.A., and McMahon, A.P. 1987. Expression of the proto-oncogene int-1 is restricted to specific neural cells in the developing mouse embryo. Cell 50: 79-88.

Wilson, M.E., Scheel, D., and German, M.S. 2003. Gene expression cascades in pancreatic development. Mech. Dev. 120: 65-80.

Yoshida, T. and Hanahan, D. 1994. Murine pancreatic ductal adenocarcinoma produced by in vitro transduction of polyoma middle $\mathrm{T}$ oncogene into the islets of Langerhans. Am. J. Pathol. 145: 671-684. 


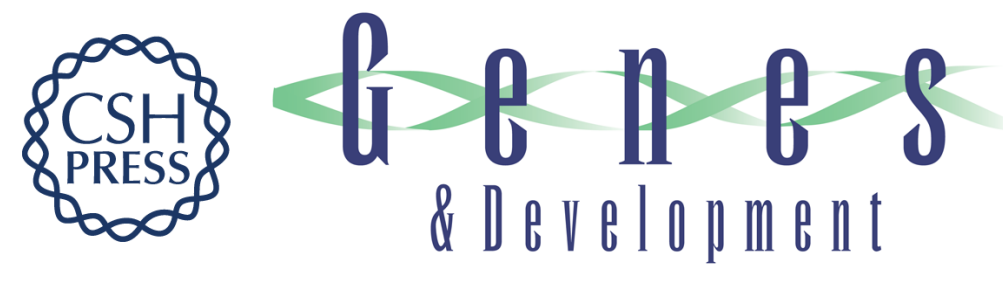

\title{
The c-myc and PyMT oncogenes induce different tumor types in a somatic mouse model for pancreatic cancer
}

\author{
Brian C. Lewis, David S. Klimstra and Harold E. Varmus
}

Genes Dev. 2003, 17:

Access the most recent version at doi:10.1101/gad.1140403

$\begin{array}{ll}\text { References } & \begin{array}{l}\text { This article cites } 47 \text { articles, } 16 \text { of which can be accessed free at: } \\ \text { http://genesdev.cshlp.org/content/17/24/3127.full.html\#ref-list-1 }\end{array}\end{array}$

License

Email Alerting Receive free email alerts when new articles cite this article - sign up in the box at the top Service right corner of the article or click here.

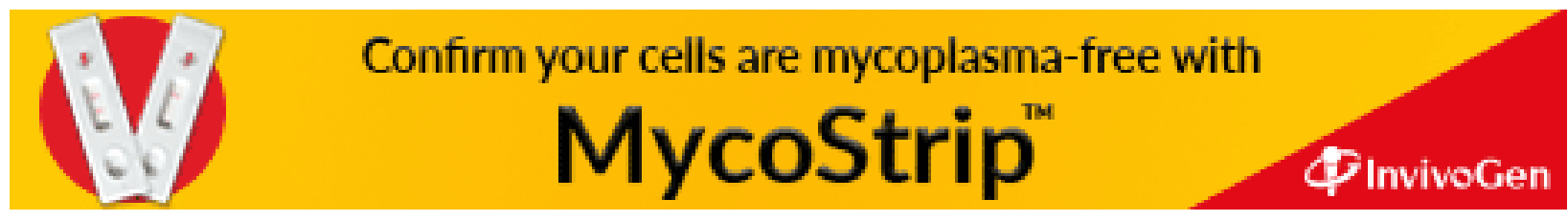

